\title{
The Design of Adaptive Learning System Based on the Collaboration of m-Learning and e-Learning Platform
}

\author{
Didik Hariyanto
}

\begin{abstract}
Currently, there are many research in e-learning system and also in m-learning system as one of the media for enhancing the student competencies. But, for combining both of them between e-learning and m-Learning, it still infrequent. In this paper, it will be provide the preliminary research on combining those systems. This paper presents the first stage of research, namely the design of adaptive learning system based on the collaboration of m-learning and e-learning system. The design of this system will be covered for different student competencies and environments. The stages of development consist of analysis, design, implementation, and testing. The evaluation of this system will be conducted by using software testing and feasibility study.
\end{abstract}

Index Terms-Adaptive, e-learning, m-learning.

\section{INTRODUCTION}

The development of technology has created breakthroughs in the development of learning. In the midst of these developments, learner has contact with the devices of mobile communication technology and internet technology and become the wave of a new trend that allows learning by electronic or more commonly known as the electronic learning (e-learning). E-learning is addressed in an effort to make the transformation of teaching and learning at the school into a digital form that is bridged by the internet technology [1]. The new trends in the e-learning development is known as the mobile learning (m-learning), a learning by using portable media such as mobile phones, smart phones, iPhone, PCTablet to access the online learning system. Use of mobile learning to support teaching and learning process is perceived can increase flexibility in teaching and learning activities [2].

By the end of 2010, in Indonesia there were 209 million mobile subscribers. This amount is 3.5 times more than internet users. In addition, $80 \%$ of new mobile phone sales in the country are equipped with internet access. This is the number of devices that help boost the penetration of internet users in Indonesia. Where, most of internet users in Indonesia come from mobile device users.

Indonesia also has the highest intensity in the world of mobile browsing, is around 633 web pages per month per person. Its mean each person opens a web page 21.1 per day on their mobile device. From this reality, it could say that Indonesia has a high level of familiarity with a cell phone. And experts also predict that internet accessed via mobile will be more popular than via PC, as revealed by Jon von

Manuscript received February 4, 2014; revised May 27, 2014.

Didik Hariyanto is with the Department of Electrical Education, College of Engineering, Yogyakarta State University, Indonesia (e-mail: didik_hr@staff.uny.ac.id).
Tetzchner, co-founder of Opera Software [3].

Mobile phone users in Indonesia are no longer based on age, strata, occupation, salary, etc. According to the results of a survey conducted by the Nielsen Company, mobile phone users in Indonesia in 2010 increased almost 3 times than in 2005 as shown in Fig. 1 [4].

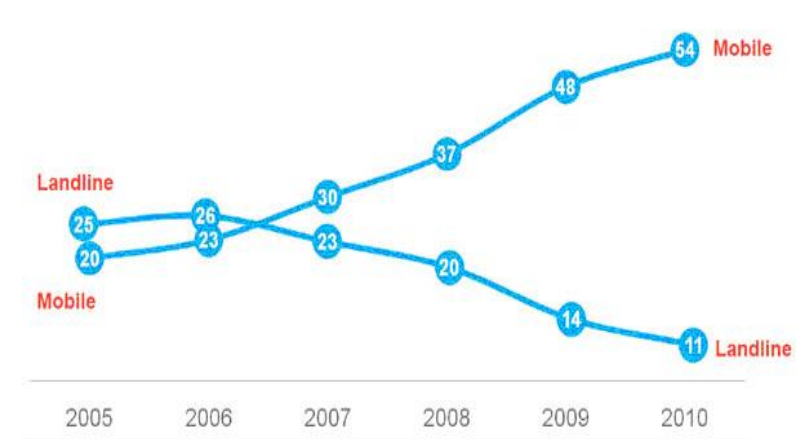

Fig. 1. Chart of hand phone ownership in Indonesia from 2005 to 2010 .

The significant increase in the number of mobile phone ownership is most likely caused by the cheapness and practicality of mobile phones can be used and taken anywhere.

According to the age category of mobile phone users in Indonesia, the result of the survey shows that 15 to 19 year old group reached the top position and 20 to 29 year old group settled in the second highest [4] (see Fig. 2).

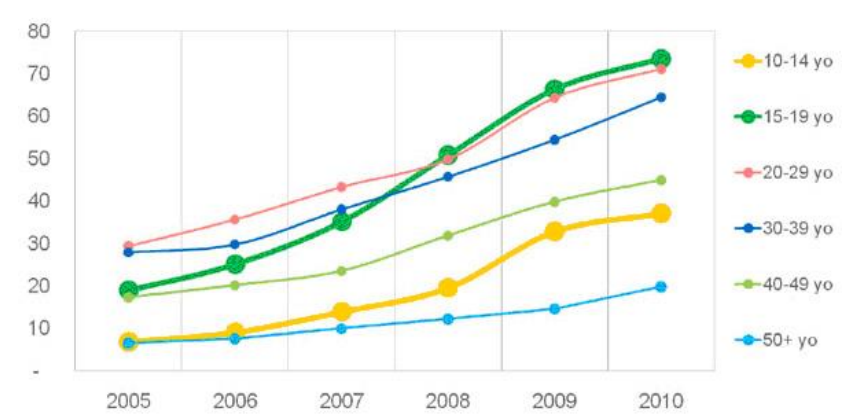

Fig. 2. Chart of mobile consumers in Indonesia based on the age group.

From the chart above, it can be concluded that the ownership of mobile devices in Indonesia is very common and the majority of mobile phone users in Indonesia is on the school age. Moreover, the application under m-learning platform can be run easily.

Currently, there are many research have been done on e-learning and m-learning. An adaptive e-learning system based on multiple student characteristics was already implemented in [5]-[7]. An adaptive m-learning was studied and performed in [8]-[11].

Most of the e-learning systems are typically accessed by 
desktop-based computers. Learners often wish that they can use various mobile devices to access the same learning content in a web-based learning environment. We try to present a combinational learning system between e-learning and m-learning system to meet the learners need. This proposed research try to develop an adaptive learning system based on students competencies that learners can accessed by desktop-based computers or by various mobile devices.

\section{LITERATURE REVIEW}

The term of e-learning can be defined as a form of information technology which is applied in the education field in the virtual school form. Definition of e-learning itself is very spacious even a portal that provides information can be covered in the scope of e-learning. However, the term of e-learning is more appropriately addressed in an effort to create a transformation of teaching and learning in school into a digital form that is transformed by the internet technology [1].

In e-learning technology, all teaching and learning that goes on in the classroom is converting to a virtual class, its mean that the same time a teacher teaching in front of a computer, while the students follow the lesson from another computer in different places. In this case, teacher and students communicate each other directly but they are not interacting face to face.

The term m-learning or mobile learning has different meanings for different communities, covering a range of use scenarios including e-learning, educational technology and distance learning, that focuses on learning using mobile devices. Mobile learning is defined as "learning across multiple contexts, through social and content interactions, using personal electronic devices" [12]. In other words, with the use of mobile devices, learners can learn anywhere and at any time [13].

Another definition of m-learning or mobile learning is learning in which learners can access learning materials, referrals and applications related to the course and the gateway to the NGL (Next Generation Learning) in which learning can be done anytime and anywhere (Ubiquitous Learning).

Adaptive learning system is usually a computer-based system that can be used for teaching and learning for teacher and students who have different level of knowledge.

According to Herman [14], the learning process is complex and many factors that could influence students to receive the lessons. Factors such basic knowledge, intelligence, learning styles of students should be accommodated in the adaptive learning system as much as possible in order to met the student's need.

\section{RESEARCH OBJECTIVES}

In general, the main goal of this paper is to design and develop an adaptive learning system based on multiple student competencies that can be accessed by desktop-based computers (e-learning) and by various mobile devices (m-learning).
In details, the objectives of this paper are outlined as follows:

1) To collect various student characteristics based on their competencies in learning.

2) To analyze the student competencies for creating the systems need analysis.

3) To design and develop the proposed method based on the need analysis.

4) To enhance the proposed method to obtain the best performance and result.

\section{PROPOSED FRAMEWORK}

The proposed method of adaptive learning system based on the collaboration of m-learning and e-learning platform has a block diagram as the Fig. 3 show. The system consists of five major parts: 1) system access module, 2) student profile module, 3) adaptive learning module, 4) personalized learning material module, and 5) web server and database server.

\section{A. System Access Module}

System access module handles registration for a new student and login/logout functions for registered students. The students can access this learning system by either computer based or mobile devices. The mobile interface adaptor is needed to convert a web page platform into mobile page form To enter this system, a registered student must login by using a username and password, and then they should be logout to end the session. Registered students have their own environment based on their competencies.

\section{B. Student Profile Module}

The functions of the student profile module are to create and update the student's profile. The student's profiles differ on each student. The student's profile created and updated by students based on their level of competence. In every level of competence, students should be take the assessment, and the result of the evaluation could be use to update the student's profile.

\section{Adaptive Learning Module}

Every student has their own environment. The adaptive learning module develops a learning style and provides an action to the learning system. This subsystem creates a learning rule based on the student's profile. The level of material, the pages or the links differ on each student's profile.

\section{Personalized Learning Material Module}

According to the adaptive learning module, the system tries to create a personalized learning material for a registered student. This subsystem provides the learning environment such as: 1) the level of material, 2) the pages or the links related to the learning rule, 3 ) the test and/or the questionnaire, 4) the user interface, etc.

\section{E. Web Server and Database Server}

Web server is software that provides data services and accept HTTP or HTTPS requests from clients, known as a web browser and send the results back in the form of pages or 
web pages which are generally formed in HTML documents. Web server in this system, not only provides data in the HTML form, but also converted the data into the mobile devices form. In this section, the system must be able to provide the best view and interface to access by the students via the web or via a mobile device. In order to obtain this scheme, it needs an interface adaptor from the web view into the mobile view. Database server stores all of the data relating with student characteristics and competencies that can be used to create the independent student environments.

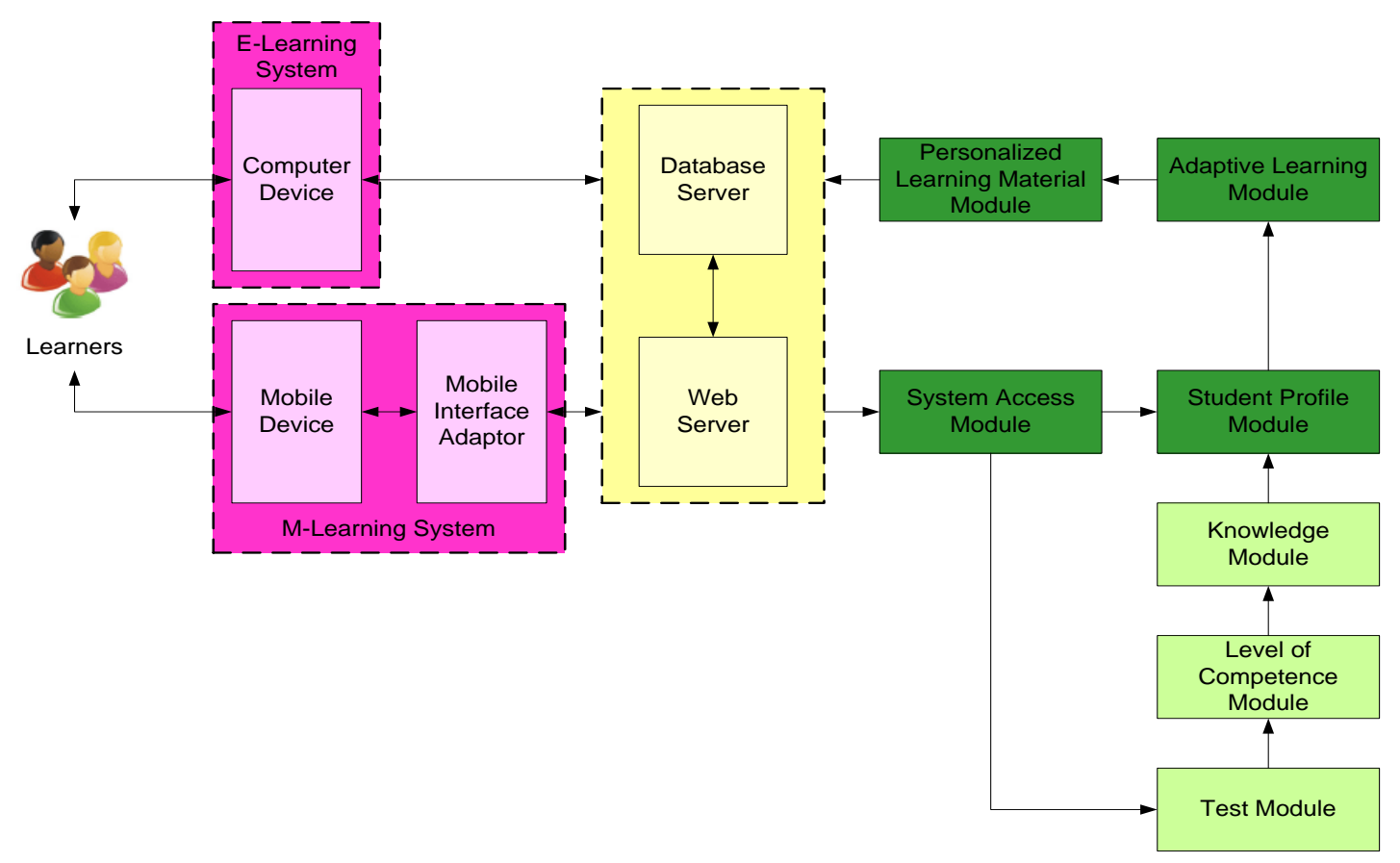

Fig. 3. Block diagram of system.

\section{DEVELOPMENT METHOD}

The development of this system using the software engineering method. There are four stages that should be completed, that it can be described as follows: 1) user needs analysis, 2) designing of system, 3) implementation or coding, 4) testing and knowing the feasibility of system [15] (see Fig. 4).

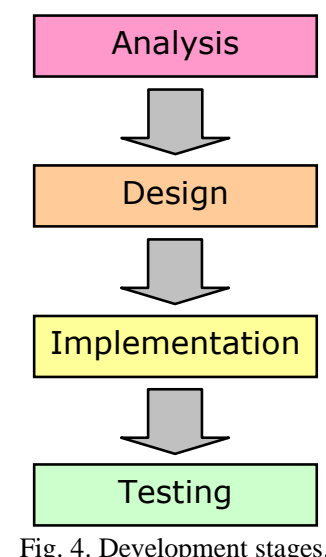

The stage in the development of this system, can described as follows:

\section{A. Analysis}

Analysis stage is the stage to identify and obtain data on the needs of what is needed in the design and implementation of systems and thinking for the next design.

In this stage, there are several items should be collect clearly, such as: 1) user needs analysis, the analysis that should be done to determine what is needed by the user, 2) workflow analysis, for knowing the workflow regarding the performance of the work will be performed by the system, 3) data analysis, for knowing what data would be processed either as input or as output, and 4) technology analysis, which is an analysis of the technology that will be used in the system.

\section{B. Design}

After data collected at this stage, the next stage is to make the design. The design can be defined as the process of implementing various kinds of techniques and principles to define the equipment, process or system in detail. The detail of the design can be described as follows:

\section{1) Context Diagram}

Context diagram or called Data Flow Diagram (DFD) Level 0 is a tool used to document the process in the system. The goal is to provide a view of the process in the system in general.

\section{2) Design of Menu}

The menu design of this software is made using a HIPO model (Hierarchy Input-Process-Output). This menu design is created with the intent of the programmer in making its application easier.

\section{3) Design of Interface}

The interface design is enable programmers in translating into a form of programming language.

\section{Implementation}

This implementation phase is the translation stage from the design material into a form of programming language. According to the context diagram, menu design and interface 
design, the programmer makes some procedures and modules easier.

Several steps that must be done in the implementation are: 1) collecting and choosing the modules that will be translated into a programming language, 2) determining which programs are needed to support the program that has been designed, 3) translating procedures, subroutines and functions of modules in the programming languages form, and 4) uniting procedures, subroutines and functions of the modules that have been made into a unified program.

\section{Testing}

Software testing is the process of executing the program to find errors. Before the program is applied, it should be assured that the program must be free of errors. Therefore, the program must be tested to find errors that may occur. Tests conducted for each module and continued with all connected modules.

The first step is debugging in which to know the initial errors. There are three kinds of errors such as: 1) language errors, 2) run-time errors, and 3) logical errors [16].

Language error or also called syntax error or grammatical error is error in the writing of source code that does not suitable with the syntax. These errors are relatively easily found and corrected, because the compiler will tell you the location when the program is compiled. Run-time error is an error that occurs when the program starts. This error will cause the program stopped before it is completed, because the compiler find the conditions have not been met. This error is also relatively easy to find, because the compiler indicated the location and what caused the mistakes. Logical error is the error of a logic program. Errors like this are hard to find, because there is no notification of the mistake and still will get the results of the program, but the results are wrong.

The next test is software testing. This phase consists of two parts, the first is Black Box Testing and the second is White Box Testing. Black Box Testing is a method of software testing that examines the functionality of an application without peering into its internal structures or workings. Black Box Testing is focused on the functional purpose of the software. This kind of test allows software developers to create a set of input conditions that will train all the functional requirements of a program.

Otherwise, White Box Testing is a method of testing software that test internal structures or workings of an application, as opposed to its functionality. This test is more specific look into the module to examine the code of existing programs, and analyze if there is a mistake or not. If there is a module that produces an output that is not in accordance with the business processes, then the source codes, variables, and parameters involved in the unit will be checked one by one and repaired, then recompiled.

\section{CONCLUSION}

The adaptive learning system based on the collaboration of e-learning and m-learning platform in this paper is expected to present learning system that match student learning environment and competencies. Student profile will be provided from the initial test to ensure the students have their environment and material as their initial competencies. This system can be accesses using either desktop based computer or mobile device. The flexibility of accessing this system hopefully could be help student to maximize their learning style.

\section{REFERENCES}

[1] Hartanto and O. W. Purbo, "E-Learning technologies based on PHP and MySQL," Elex Media Komputindo, 2002.

[2] A. Yudianto. (2011). Mobile learning. [Online]. Available: http://www.elearning.web.id.

[3] Metrokomp. (2011). Berprospek: Mendulang rupiah dari industri mobile. [Online]. Available: http://www.metrokomp.com.

[4] Teknojurnal. (2011). Perkembangan pasar handphone di Indonesia dari tahun 2005 hingga 2010. [Online]. Available: http://www.teknojurnal.com.

[5] H. D. Surjono and J. R. Maltby, "Adaptive educational hypermedia based on multiple student characteristics," in Proc. the Second International Conference on Web-based Learning, Melbourne, Australia, August 2003.

[6] H. D. Surjono, "The design and implementation of an adaptive e-learning system," in Proc. The International Symposium Open, Distance, and E-learning, November 2007.

[7] H. D. Surjono, "Empirical evaluation of an adaptive e-learning system and the effects of knowledge, learning styles and multimedia mode on student achievement," in Proc. the UiTM International Conference on Elearning, Universiti Teknologi MARA, Shah Alam, Malaysia, December, 2007.

[8] X. Y. Zhao and T. Okamoto, "A device-independent system architecture for adaptive mobile learning," in Proc. Eight IEEE International Conference on Advanced Learning Technologies, 2008.

[9] M. Alnabhan, "An integrated context adaptive m-learning system," in Proc. the European, Mediterranean \& Middle Eastern Conference on Information Systems, Athens, Greece, May 2011.

[10] M. Shanmugapriya, "Developing a mobile adaptive test (MAT) in an m-learning environment for android based 3G mobile devices," International Journal on Computer Science and Engineering, vol. 4 no. 2, February 2012.

[11] H. M. Ghadirli and M. Rastgarpour, "An adaptive and intelligent tutor by expert systems for mobile devices," International Journal of Managing Public Sector Information and Communication Technologies, vol. 3, no. 1, September 2012.

[12] H. Crompton, "A historical overview of mobile learning: Toward learner-centered education," in Handbook of Mobile Learning, Z. L. Berge and L. Y. Muilenburg, Eds., Florence, KY: Routledge, 2013, pp. 3-14.

[13] M. Crescente, L. Lee, and L. Doris, "Critical issues of m-learning: design models, adoption processes, and future trends," Journal of the Chinese Institute of Industrial Engineers, vol. 28, no. 2, pp. 111-123, March 2011.

[14] H. D. Surjono, "The design of adaptive e-learning system based on student's learning styles," International Journal of Computer Science and Information Technologies, vol. 2, no. 5, 2011.

[15] R. S. Pressman, Software Engineering: A Practitioner's Approach, McGraw-Hill, New York, 10020, 2001.

[16] H. M. Jogiyanto, Analisis Dan Desain, Yogyakarta: Andi Offset, 1989.

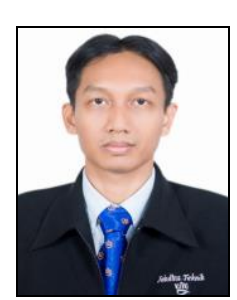

Didik Hariyanto is a lecturer at the Department of Electrical Education, College of Engineering, Yogyakarta State University, Indonesia. He finished his master degree at Sepuluh Nopember Institute of Technology, Indonesia in Multimedia Intelligent Network in 2006.

He teaches computer programming, educational media, and multimedia design. His research areas include computer based learning, e-learning and multimedia. At the moment he is a head of web division at computer centre, Yogyakarta State University. He is also a reviewer at one of accredited journal in Indonesia (Telkomnika Journal). 